\title{
Effect of abhrak bhasma and silicon dioxide on hepatic and renal glutathione status in rats: hepatoprotection testing against single dose carbon tetrachloride induced hepatotoxicity
}

\author{
Parashuram Teli *, Jaywant Jadhav, Aruna Kanase \\ Cell Biology Section, Dept. of Zoology, Shivaji University, Kolhapur-416 004, MH, India \\ *Corresponding authorE-mail: arunakanase@gmail.com
}

\begin{abstract}
Background: Glutathione (GSH) is an important intracellular antioxidant. Intrahepatic GSH levels are depleted in liver diseases. Objectives: In present study, effect of abhrak bhasma (an Ayurvedic drug) and silicon dioxide $\left(\mathrm{SiO}_{2}\right)$ on hepatic and renal GSH status against $\mathrm{CCl}_{4}$ intoxicated male albino rats were investigated.

Methods: Single dose of $\mathrm{CCl}_{4}(3.0 \mathrm{ml} / \mathrm{kg}$ body wt, sc) was used to induce hepatotoxicity. Graded doses $(10,20,30 \mathrm{and} 40 \mathrm{mg} / \mathrm{kg}$ body wt) of abhrak bhasma and $\mathrm{SiO}_{2}$ were concurrently given with $\mathrm{CCl}_{4}$. Hepatic and renal GSH content was studied after 24 hrs.

Results: Results showed that rats exposed to $\mathrm{CCl}_{4}$ exhibited decreased GSH in liver. It was counteracted and maintained to normal levels by the treatment of abhrak bhasma (minimum protective dose-10mg). $\mathrm{SiO}_{2}$ treatments did not affect GSH activity in liver significantly. Single dose of $\mathrm{CCl}_{4}$ had not influenced GSH content in kidney alone or with any of the doses of abhrak bhasma or $\mathrm{SiO}_{2}$.

Conclusion: $\mathrm{CCl}_{4}$ single dose depletes GSH content significantly in liver but not in kidney. These results suggest that single dose treatment of abhrak bhasma (10mg onwards) protects GSH content and thus manages $\mathrm{CCl}_{4}$ induced free radical generation scavenging them.
\end{abstract}

Keywords: Abhrak Bhasma, Antioxidant, Glutathione, Hepatotoxicity, Silicon Dioxide.

\section{Introduction}

Liver and kidneys play a vital role in the metabolism, detoxification of xenobiotics by biotransformation and protect clearance (Edward \& Celia, 1998; Majno \& Joris; Nebbia, 2001). Carbon tetrachloride $\left(\mathrm{CCl}_{4}\right)$ is one of the most commonly used hepatotoxin in the experimental study of liver diseases. $\mathrm{CCl}_{4}$ induced oxidative stress is associated with increased free radical generation and lipid peroxidation (LPO) (Recknagel et al, 1992; Burk et al, 1984; Kaplowitz et al, 1986; Teli et al., 2014); which leads to fatty degeneration in liver. Oxidative damage induced by free radicals can be prevented by the use of antioxidants. LPO and cellular antioxidant defense have importance in the oxidative stability. Ongoing oxidative processes and decreased intrahepatic glutathione level induced oxidative stress in liver is known (Ljubuncic et al., 2000; Ljubuncic \& Bomzon, 2006). Endogenous glutathione, a thiol compound synthesized mainly in liver plays an antioxidant role by reducing reactive oxygen species (ROS) formed during cellular metabolism and protects cells (Parke \& Piotrowski, 1996; Deneke, 2000). It has negative correlation with LPO in liver and kidney.

Many researchers have focused on natural antioxidants for the treatment of oxidative stress induced complications. Abhrak bhasma is a commonly used Ayurvedic drug in various disorders including hepatitis (Sharma, 1977). In therapy it is useful in antiaging treatment, rejuvenation treatment etc. It has been reported for a strong immune system, rapidly increasing the production of T-Cell phagocytes. In our earlier work abhrak bhasma has protected single dose of $\mathrm{CCl}_{4}$ induced increased malondialdehyde content in liver (Teli et al., 2014). Thus, to study the possible scavenging activity in vivo; it was planned to study glutathione (GSH) content in single dose of $\mathrm{CCl}_{4}$ induced hepatotoxicity and associated changes in kidney. $\mathrm{SiO}_{2}$ was used as silicon control for abhrak bhasma.

\section{Material and methods}

\subsection{Animal}

Male albino rats, Rattus norvegicus weighing about 130-140g each were used for experiment. They were bred and maintained in the departmental animal house (Reg. No. 233/CPCSEA) under standard conditions and were given standard pellet diet (prepared by Amrit feeds, Sangli, MS, India). Food and water were provided ad libitum.

\subsection{Preparation of abhrak bhasma and silicon dioxide}

Abhrak bhasma was prepared in the laboratory as described in Rasa Ratna Sammucchaya (Sharma, 1977). $\mathrm{SiO}_{2}$ treatment was given as silicon control. To study dose dependent effects of abhrak bhasma and $\mathrm{SiO}_{2}$ on GSH content of liver and kidney, different doses viz. $10,20,30$ and $40 \mathrm{mg} / \mathrm{kg}$ body wt were administered orally with honey. Honey control rats that were used; showed data as normal rat. Therefore, honey control data is not presented.

\subsection{Experimental design}


The experimental animals were divided into following groups, each comprising of six animals.

Group 1- The rats were maintained as normal without any treatment.

Group 2- Hepatotoxicity induced by single dose of $3.0 \mathrm{ml} \mathrm{CCl} /$ $\mathrm{kg}$ body wt for $24 \mathrm{hrs} \mathrm{sc}$.

Group 3-10 mg abhrak bhasma/kg body wt was given po.

Group 4- $20 \mathrm{mg}$ abhrak bhasma/kg body wt was given po.

Group 5- $30 \mathrm{mg}$ abhrak bhasma/kg body wt was given po.

Group 6- $40 \mathrm{mg}$ abhrak bhasma/kg body wt was given po.

Group 7- $10 \mathrm{mg} \mathrm{SiO} / \mathrm{kg}$ body wt was given po.

Group 8- $20 \mathrm{mg} \mathrm{SiO} / \mathrm{kg}$ body wt was given po.

Group 9- $30 \mathrm{mg} \mathrm{SiO} / \mathrm{kg}$ body wt was given po.

Group 10- $40 \mathrm{mg} \mathrm{SiO} / 2 \mathrm{~kg}$ body wt was given po

Group 11- $\mathrm{CCl}_{4}(3.0 \mathrm{ml} / \mathrm{kg}$ body wt) sc $+10 \mathrm{mg}$ abhrak bhasma/ $\mathrm{kg}$ body wt po for $24 \mathrm{hrs}$.

Group 12- $\mathrm{CCl}_{4}(3.0 \mathrm{ml} / \mathrm{kg}$ body wt $) \mathrm{sc}+20 \mathrm{mg}$ abhrak bhasma/ $\mathrm{kg}$ body wt po for $24 \mathrm{hrs}$.

Group $13-\mathrm{CCl}_{4}(3.0 \mathrm{ml} / \mathrm{kg}$ body wt $) \mathrm{sc}+30 \mathrm{mg}$ abhrak bhasma/ $\mathrm{kg}$ body wt po for $24 \mathrm{hrs}$.

Group 14- $\mathrm{CCl}_{4}(3.0 \mathrm{ml} / \mathrm{kg}$ body wt $) \mathrm{sc}+40 \mathrm{mg}$ abhrak bhasma/ $\mathrm{kg}$ body wt po for $24 \mathrm{hrs}$.

Group $15-\mathrm{CCl}_{4}(3.0 \mathrm{ml} / \mathrm{kg}$ body wt $) \mathrm{sc}+10 \mathrm{mg} \mathrm{SiO} / 2 \mathrm{~kg}$ body wt po for $24 \mathrm{hrs}$.

Group 16- $\mathrm{CCl}_{4}(3.0 \mathrm{ml} / \mathrm{kg}$ body wt $) \mathrm{sc}+20 \mathrm{mg} \mathrm{SiO}_{2} / \mathrm{kg}$ body wt po for $24 \mathrm{hrs}$.

Group 17- $\mathrm{CCl}_{4}(3.0 \mathrm{ml} / \mathrm{kg}$ body wt $) \mathrm{sc}+30 \mathrm{mg} \mathrm{SiO}_{2} / \mathrm{kg}$ body wt po for $24 \mathrm{hrs}$.

Group $18-\mathrm{CCl}_{4}(3.0 \mathrm{ml} / \mathrm{kg}$ body wt $) \mathrm{sc}+40 \mathrm{mg} \mathrm{SiO}_{2} / \mathrm{kg}$ body wt po for $24 \mathrm{hrs}$.

The rats were killed after $24 \mathrm{hrs}$ by giving deep ether anesthesia and liver and kidney tissues were separated from animals and taken for GSH estimation.

\subsection{Preparation of tissue homogenate}

The livers and kidneys were perfused with chilled phosphate buffer saline (PBS). They were dissected out, minced and washed with PBS. The minces were then suspended in $0.25 \mathrm{M}$ sucrose containing $10 \mathrm{mM}$ Tris- $\mathrm{HCl}$ buffer ( $\mathrm{pH} 7.0$ ) homogenizing buffer $(\mathrm{HB})$ and washed 3 times with HB. The minces were homogenized with Potter-Elvehjam homogenizer with Teflon piston at 1500 RPM with 8 up and down strokes. The liver and kidney homogenates were centrifuged in refrigerated centrifuge at $4^{\circ} \mathrm{C}$ for 10 minutes at $3000 \mathrm{x}$ g. The supernatants were collected and used for GSH estimation.

\subsection{Estimation of GSH}

Biochemical assay of GSH was performed as per method proposed by Grunert \& Phillips (1951).

Bioassay was conducted in different tubes, one blank and sample tube as per experimental schedule of rats. To blank tube was added $6.0 \mathrm{ml} 0.25 \mathrm{M}$ sucrose in homogenate buffer and to sample tubes added $6.0 \mathrm{ml}$ of supernatants. One $\mathrm{ml}$ sodium nitroprusside and $1.0 \mathrm{ml}$ sodium cyanide solution in sodium carbonate were added to all tubes. Optical densities were measured at $520 \mathrm{~nm}$ against blank.

\subsection{Statistical analysis}

All the experimental data was statistically evaluated and expressed as mean \pm standard error for six rats in each group. Hypothesis testing methods included one way analysis of variance (ANOVA) followed by students ' $\mathrm{t}$ ' test. Values $\mathrm{P}<0.05, \mathrm{P}<0.01$ and $\mathrm{P}<0.001$ were considered to point out statistical significance.

\section{Results and discussion}

Table 1: Abhrak bhasma $(\mathrm{AB})$ \& $\mathrm{SiO}_{2}$ Influenced Alterations in $\mathrm{GSH}$ Contents in Liver and Kidney of Rats by Single Dose of Treatment.

\begin{tabular}{|c|c|c|c|c|}
\hline \multirow[b]{2}{*}{ Groups } & \multicolumn{2}{|c|}{ Liver } & \multicolumn{2}{|c|}{ Kidney } \\
\hline & mg/gm & $\mu \mathrm{g} / \mathrm{mg}$ & $\mathrm{mg} / \mathrm{gm}$ & $\mu \mathrm{g} / \mathrm{mg}$ \\
\hline Normal & $27.97 \pm 1.28$ & $.22 \pm 0.002$ & $13.10 \pm 0.62$ & $0.14 \pm 0.009$ \\
\hline $\begin{array}{l}\mathrm{CCl}_{4}[3.0 \\
\mathrm{ml}] \mathrm{sc}\end{array}$ & $21.25 \pm 2.21^{\mathrm{a}}$ & $0.14 \pm 0.013^{c}$ & $11.10 \pm 0.61$ & $0.14 \pm 0.011$ \\
\hline $\begin{array}{l}\mathrm{CCl}_{4}+ \\
10 \mathrm{mg} \mathrm{AB}\end{array}$ & $25.13 \pm 1.81$ & $0.20 \pm 0.002^{\mathrm{y}}$ & $12.10 \pm 0.04$ & $0.13 \pm 0.003$ \\
\hline $\begin{array}{l}\mathrm{CCl}_{4}+ \\
20 \mathrm{mg} \mathrm{AB}\end{array}$ & $25.64 \pm 2.31$ & $0.21 \pm 0.006^{\mathrm{z}}$ & $13.01 \pm 0.21$ & $0.13 \pm 0.006$ \\
\hline $\begin{array}{l}\mathrm{CCl}_{4}+ \\
30 \mathrm{mg} \mathrm{AB}\end{array}$ & $26.11 \pm 1.91$ & $0.21 \pm 0.009^{y}$ & $12.90 \pm 0.15$ & $0.13 \pm 0.004$ \\
\hline $\begin{array}{l}\mathrm{CCl}_{4}+ \\
40 \mathrm{mg} \mathrm{AB}\end{array}$ & $28.01 \pm 2.84$ & $0.23 \pm 0.006^{\mathrm{z}}$ & $13.01 \pm 0.31$ & $0.14 \pm 0.006$ \\
\hline $\begin{array}{l}\mathrm{CCl}_{4}+ \\
10 \mathrm{mg} \mathrm{SiO}_{2}\end{array}$ & $39.21 \pm 3.11^{\mathrm{bz}}$ & $0.28 \pm 0.012^{\mathrm{cz}}$ & $11.34 \pm 0.97$ & $0.13 \pm 0.004$ \\
\hline $\begin{array}{l}\mathrm{CCl}_{4}+ \\
20 \mathrm{mg} \mathrm{SiO}_{2}\end{array}$ & $36.82 \pm 2.84^{\text {ay }}$ & $0.27 \pm 0.008^{\mathrm{cz}}$ & $11.71 \pm 0.74$ & $0.14 \pm 0.001$ \\
\hline $\begin{array}{l}\mathrm{CCl}_{4}+ \\
30 \mathrm{mg} \mathrm{SiO}_{2}\end{array}$ & $35.14 \pm 1.33^{\mathrm{bz}}$ & $0.28 \pm 0.009^{\mathrm{cz}}$ & $9.24 \pm 0.96^{\mathrm{b}}$ & $0.11 \pm 0.007^{\mathrm{ax}}$ \\
\hline $\begin{array}{l}\mathrm{CCl}_{4}+ \\
40 \mathrm{mg} \mathrm{SiO}_{2}\end{array}$ & $32.19 \pm 1.09^{\text {ay }}$ & $0.27 \pm 0.008^{\mathrm{cz}}$ & $10.10 \pm 0.98$ & $0.11 \pm 0.009^{\mathrm{y}}$ \\
\hline
\end{tabular}

(Values are mean \pm SEM of 6 animals. $\mathrm{P}$ values: $\mathrm{a}<0.05 ; \mathrm{b}<0.01 ; \mathrm{c}$ $<0.001$ vs. normal)

Glutathione is a reducing agent that is in high concentrations in mammalian tissues. It is an antioxidant, rich in cytosol. GSH reacts efficiently with oxidizing substances such as active oxygen species and lipid peroxidation. Several studies have revealed that status of GSH contents is markedly decreased in hepatic injury (Purucker et al., 1995). It is caused by reduced concentrations of liver GSH. In present work, we investigated abhrak bhasma and $\mathrm{SiO}_{2}$ induced alterations in GSH status of liver and kidney of male albino rat, during hepatotoxicity induced by single dose of $\mathrm{CCl}_{4}$ at 24 hrs. The results were shown in table No. 1 and 2 .

Table 2: Abhrak Bhasma (AB) \& Sio2 Influenced Alterations in GSH Contents in Liver \& Kidney of Rats during Induction of Toxicity by Single Dose of $\mathrm{Ccl} 4$.

\begin{tabular}{lcccc}
\hline & \multicolumn{2}{c}{ Liver } & \multicolumn{2}{c}{ Kidney } \\
\cline { 2 - 5 } Groups & $\begin{array}{c}\mathrm{mg} / \mathrm{gm} \\
\text { Tissue }\end{array}$ & $\begin{array}{c}\mu \mathrm{g} / \mathrm{mg} \text { Pro- } \\
\text { tein }\end{array}$ & $\begin{array}{c}\mathrm{mg} / \mathrm{gm} \\
\text { Tissue }\end{array}$ & $\begin{array}{c}\mu \mathrm{g} / \mathrm{mg} \\
\text { Protein }\end{array}$ \\
\hline Normal & $28.96 \pm 0.65$ & $0.22 \pm 0.003$ & $14.57 \pm 0.71$ & $0.15 \pm 0.004$ \\
$10 \mathrm{mg} \mathrm{AB}$ & $28.64 \pm 0.11$ & $0.25 \pm 0.006$ & $13.34 \pm 0.54$ & $0.13 \pm 0.008^{\mathrm{a}}$ \\
$20 \mathrm{mg} \mathrm{AB}$ & $29.39 \pm 0.14$ & $0.26 \pm 0.009^{\mathrm{b}}$ & $15.22 \pm 0.31$ & $0.15 \pm 0.001$ \\
$30 \mathrm{mg} \mathrm{AB}$ & $29.35 \pm 0.14$ & $0.24 \pm 0.004$ & $15.36 \pm 0.65$ & $0.16 \pm 0.004$ \\
$40 \mathrm{mg} \mathrm{AB}$ & $32.19 \pm 0.61$ & $0.26 \pm 0.005$ & $15.54 \pm 0.94$ & $0.16 \pm 0.008^{\mathrm{c}}$ \\
$10 \mathrm{mg}$ & $44.19 \pm 0.69^{\mathrm{c}}$ & $0.31 \pm 0.010^{\mathrm{c}}$ & $14.14 \pm 0.63$ & $0.15 \pm 0.003^{\mathrm{b}}$ \\
$\mathrm{SiO}_{2}$ & & & & \\
$20 \mathrm{mg}$ & $55.24 \pm 0.34^{\mathrm{c}}$ & $0.42 \pm 0.014^{\mathrm{c}}$ & $15.24 \pm 1.03$ & $0.17 \pm 0.004^{\mathrm{b}}$ \\
$\mathrm{SiO}_{2}$ & & & & \\
$30 \mathrm{mg}$ & $81.54 \pm 3.00^{\mathrm{c}}$ & $0.72 \pm 0.004^{\mathrm{c}}$ & $13.71 \pm 1.56$ & $0.14 \pm 0.009^{\mathrm{c}}$ \\
$\mathrm{SiO}_{2}$ & & & & \\
$40 \mathrm{mg}$ & $81.23 \pm 2.85^{\mathrm{c}}$ & $0.75 \pm 0.007^{\mathrm{c}}$ & $12.29 \pm 0.96$ & $0.15 \pm 0.008^{\mathrm{b}}$ \\
$\mathrm{SiO}_{2}$ & & & &
\end{tabular}

(Values are mean \pm SEM of 6 animals. $\mathrm{P}$ values: $\mathrm{a}<0.05 ; \mathrm{b}<0.01 ; \mathrm{c}$

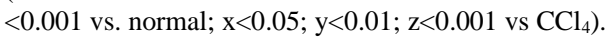

GSH content in liver of normal rat exhibited $28.96 \pm 0.65 \mu \mathrm{g} / \mathrm{gm}$ tissue, which was not altered by the administration of 10,20 and $30 \mathrm{mg}$ abhrak bhasma and remained in its normal range. When treatment of 40mg abhrak bhasma was given to the normal rat, GSH content was marginally increased (1.11 fold). Thus, abhrak bhasma alone with $10 \mathrm{mg}$ through $30 \mathrm{mg}$ doses are not affecting GSH contents while highest dose used marginally increased the GSH content. Similar doses of $\mathrm{SiO}_{2}$ when given to the normal rat in same experimental condition, it showed significant elevation in GSH contents $(\mathrm{P}<0.001)$ which was noted at all $\mathrm{SiO}_{2}$ doses studied. As contrast to abhrak bhasma, $\mathrm{SiO}_{2}$ given alone showed highly significant increase in hepatic GSH, but not in renal GSH con- 
tent. These results indicate that $\mathrm{SiO}_{2}$ induces GSH content in liver. It is dose dependent in 10, 20 and $30 \mathrm{mg}$. while $30 \mathrm{mg}$ and $40 \mathrm{mg}$ dose showed similar levels. Similar trend was also expressed in GSH status calculated per mg protein. Kidney GSH content remained unaffected either with abhrak bhasma doses or with $\mathrm{SiO}_{2}$ doses used indicating single doses of any of the drugs is not influencing kidney GSH. These results are similar to malondialdehyde contents of kidney studied earlier (Teli et al, 2014); indicating free radical and free radical scavenger status is steady and normal.

Single dose of $\mathrm{CCl}_{4}$ reduced GSH significantly $(\mathrm{P}<0.05)$ in liver. Simultaneous treatment of abhrak bhasma (all the doses) normalized the GSH content. Minimum dose required was $10 \mathrm{mg}$. But contrast to these results all the doses of $\mathrm{SiO}_{2}$ induced GSH content in $\mathrm{CCl}_{4}$ treated rats levels of which were significantly high over the levels reported in normal rat. These observations suggest that $\mathrm{SiO}_{2}$ all the doses are potent inducers of GSH content in presence of $\mathrm{CCl}_{4}$ so also in absence of $\mathrm{CCl}_{4}$. But in kidney $\mathrm{SiO}_{2}$ is not influencing $\mathrm{GSH}$ content either in presence of $\mathrm{CCl}_{4}$ or in absence of $\mathrm{CCl}_{4}$. same is true with abhrak bhasma doses in kidney. These results also show similarity with LPO product contents (Teli et al, 2014). Thus, indicating in kidney free radical (MDA) and free radical scavenger $(\mathrm{GSH})$ status remains independent of single doses of $\mathrm{CCl}_{4}$, abhrak bhasma and $\mathrm{SiO}_{2}$.

Thus, primary dose response of $\mathrm{CCl}_{4}$ toxicity in liver is protected by minimum dose of abhrak bhasma managing reduction in MDA (Teli et al, 2014) with increased GSH/ natural free radical scavenger. Single doses of $\mathrm{SiO}_{2}$ are capable of inducing GSH content in normal and $\mathrm{CCl}_{4}$ (single dose) treated rat liver. But GSH content of kidney is inert to $\mathrm{CCl}_{4}$ single dose treatment, $\mathrm{CCl}_{4}+$ single doses of abhrak bhasma (10/20/30/40mg), $\mathrm{CCl}_{4}+\mathrm{SiO}_{2}(10 / 20 / 30 / 40 \mathrm{mg})$, abhrak bhasma alone single doses (10/20/30/40mg) and $\mathrm{SiO}_{2}$ alone single doses (10/20/30/40mg).

These studies require need of other parameter studies to resolve hepatoprotective mechanism of action/s of abhrak bhasma against $\mathrm{CCl}_{4}$ induced toxicity.

\section{Acknowledgements}

Authors are thankful to Dr. S. S. Patil for his contribution in abhrak bhasma preparation and other constructive suggestions.

\section{References}

[1] Burk RF, Lane JM \& Patel K (1984), Relationship of oxygen and glutathione in protection against carbon tetrachloride-induced hepatic microsomal lipid peroxidation and covalent binding in the rat. Rationale for the use of hyperbaric oxygen to treat carbon tetrachloride

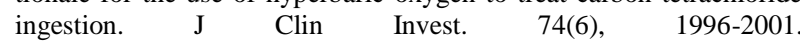
http://dx.doi.org/10.1172/JCI111621.

[2] Deneke S (2000), Thiol-based antioxidants. Curr. Top. Cell Reg. 36, 151. http://dx.doi.org/10.1016/S0070-2137 (01)80007-8.

[3] Edward AL \& Celia JR (1998), Xenobiotic Metabolizing Enzymes of the Kidney" Toxicologic Pathology 26(1), 18-25. http://dx.doi.org/10.1177/019262339802600102.

[4] Grunert RR \& Phillips P H (1951), Determination of glutathione. Arch Biochem, 30(2), 217-225.

[5] Kaplowitz N, Aw TY, Simon FR \& Stolz A (1986), Drug induced hepatotoxicity. Ann Intern Med; 104, 826-39. http://dx.doi.org/10.7326/0003-4819-104-6-826.

[6] Ljubuncic P, Tanne Z \& Bomzon A (2000), Evidence of a systemic phenomenon for oxidative stress in cholestatic liver disease. Gut, 47 (5), 710-716. http://dx.doi.org/10.1136/gut.47.5.710.

[7] Ljubuncic P \& Bomzon A (2006), Liver disease, oxidative stress and ursodeoxycholic acid," in Liver Diseases: Biochemical Mechanisms and New Therapeutic Insights, S. Ali, S. L. Friedman, and D. A. Mann, Eds., Science, New Hampshire, NH, USA.

[8] Majno G \& Joris I (2004), Cells, Tissues, and Disease, Principals of General Pathology, 2nd Edi. Oxford University Press, New York and Oxford.

[9] Nebbia C (2001), Biotransformation enzymes as determinants of xenobiotic toxicity in domestic animals.Vet J., 161(3): 238-52. http://dx.doi.org/10.1053/tvj1.2000.0561.
[10]Parke DV and Piotrowski J (1996), Glutathione: Its role in detoxification of reactive oxygen species and environmental chemicals. Acta Pol Toxicol, 4(1).

[11]Purucker E, Wernze H \& Krandik G (1995), Glutathione in plasma, liver and kidney in the development of $\mathrm{CCl} 4$-induced cirrhosis of the

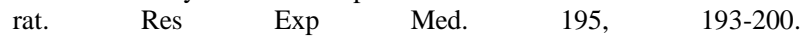
http://dx.doi.org/10.1007/BF02576788.

[12]Recknagel RO, Glende EA, Dolack JA, Walter RL (1992), Mechanism of carbon tetrachloride toxicity. Pharmacol ther, 43, 139-154. http://dx.doi.org/10.1016/0163-7258 (89)90050-8.

[13]Sharma S (1977) Rasa Ratna Samuchhaya, Published by Motilal Banrasidas, New Delhi, 72-108.

[14]Teli P, Jadhav J \& Kanase A (2014), Comparison of abhrak bhasma and silicon dioxide efficacy against single dose of carbon tetrachloride induced hepatotoxicity in rat by evaluation of lipid peroxidation. International journal of pharmaceutical science and research, 2 (7): 186196. 